\title{
Metallomics
}

Check for updates

Cite this: Metallomics, 2018, 10, 1089

Received 2nd May 2018 Accepted 4th July 2018

DOI: $10.1039 / \mathrm{c} 8 \mathrm{mt} 00098 \mathrm{k}$

rsc.li/metallomics

\section{Nickel(II)-promoted specific hydrolysis of zinc finger proteins $\dagger$}

\author{
Agnieszka Belczyk-Ciesielska, ${ }^{\mathrm{a}}$ Brigitta Csipak, ${ }^{\mathrm{b}}$ Bálint Hajdu, ${ }^{\mathrm{b}}$ Aleksandra Sparavier, ${ }^{a}$ \\ Masamitsu N. Asaka, ${ }^{c}$ Kyosuke Nagata, ${ }^{c}$ Béla Gyurcsik (D) ${ }^{\star b}$ and Wojciech Bal (D)*a
}

\begin{abstract}
In this work we demonstrate that the previously described reaction of sequence specific $\mathrm{Ni}(I)$-dependent hydrolytic peptide bond cleavage can be performed in complex metalloprotein molecules, such as the $\mathrm{Cys}_{2} \mathrm{His}_{2}$ zinc finger proteins. The cleavage within a zinc finger unit possessing a (Ser/Thr)-X-His sequence is not hindered by the presence of the $\mathrm{Zn}(\mathrm{I})$ ions. It results in loss of the $\mathrm{Zn}(\mathrm{II})$ ion, oxidation of the $\mathrm{SH}$ groups and thus, in a collapse of the functional structure. We show that such natural Ni(॥)-cleavage sites in zinc finger domains can be edited out without compromising the DNA binding specificity. Inserting a $\mathrm{Ni}($ II)-susceptible sequence between the edited zinc finger and an affinity tag allows for removal of the latter sequence by $\mathrm{Ni}(I)$ ions after the protein purification. We have shown that this reaction can be executed even when a metal ion binding $\mathrm{N}$-terminal His-tag is present. The cleavage product maintains the native zinc finger structure involving $\mathrm{Zn}(I)$ ions. Mass spectra revealed that a $\mathrm{Ni}(I)$ ion remains coordinated to the hydrolyzed protein product through the N-terminal (Ser/Thr)-X-His tripeptide segment. The fact that the $\mathrm{Ni}(I)$-dependent protein hydrolysis is influenced by the $\mathrm{Ni}(I)$ concentration, $\mathrm{pH}$ and temperature of the reaction provides a platform for novel regulated DNA effector design.
\end{abstract}

\section{Significance to metallomics}

The present study shows that $\mathrm{Cys}_{2} \mathrm{His}_{2}$ zinc finger proteins including (S/T)XH sequence can be hydrolytically cleaved by Ni(II) ions. The cleavage involving any of the histidines bound to $\mathrm{Zn}$ (II)-ions abolishes the functional structure of the affected finger. Designed Ni(II) sensitive sequences however, allow for removal of affinity purification tags (even metal ion-binding oligo-His tag) or other regulatory fusion protein elements. Our study contributes to understanding of the effect of $\mathrm{Ni}(\mathrm{II})$ ions on such a complex and sensitive metalloprotein. At the same time it opens a perspective for novel zinc finger fusion protein design which can be activated/regulated by $\mathrm{Ni}($ II)-induced cleavage.

\section{Introduction}

Transcription factors of the $\mathrm{Cys}_{2} \mathrm{His}_{2}$ zinc finger (ZF) family control gene functions in living organisms by binding to specific nucleic acid sequences. ${ }^{1,2}$ The canonical sequence of a finger unit, able to form a $\beta \beta \alpha$ secondary structure with a tetrahedral metal ion binding site, was defined on the basis of a library of native sequences as (Tyr,Phe)-X-Cys- $\mathrm{X}_{2,4}$-Cys- $\mathrm{X}_{3}$-Phe$\mathrm{X}_{5}$-Leu- $\mathrm{X}_{2}$ - ${ }_{\text {His }}-\mathrm{X}_{3-5}$ - $\underline{\text { His }}$ (Zn(II) binding residues underlined). ${ }^{3} \mathrm{ZF}$ proteins possess a modular assembly in which each ZF unit

\footnotetext{
${ }^{a}$ Institute of Biochemistry and Biophysics, Polish Academy of Sciences, Pawinskiego 5a; 02-106, Warsaw, Poland. E-mail: wbal@ibb.waw.pl; Fax: +48-226584636

${ }^{b}$ Department of Inorganic and Analytical Chemistry, University of Szeged, Dóm tér 7, Szeged H-6720, Hungary. E-mail: gyurcsik@chem.u-szeged.hu; Fax: +3662544340

${ }^{c}$ Nagata Special Laboratory, Faculty of Medicine, University of Tsukuba, 1-1-1 Tennodai, Tsukuba 305-8575, Japan

$\dagger$ Electronic supplementary information (ESI) available. See DOI: 10.1039/c8mt00098k
}

recognizes three subsequent nucleotides. ${ }^{1,2}$ This allows for targeting DNA sequences of a 9-12 base pair length by a cascade of such units in a ZF protein. ${ }^{4-9}$ Artificial ZF proteins with desired DNA specificities can be obtained by altering the amino acids in the $\alpha$-helical DNA base recognition region according to the well-known methodologies. ${ }^{10-14}$ A popular approach is to utilize effector molecules (i.e. ligand or metalbinding regulatory sequences or an endonuclease catalytic domain) linked to ZF proteins, thereby providing an opportunity to generate artificial transcription factors or enzymes for specific DNA actions. ${ }^{2,15-25}$

Previously we reported on $\mathrm{Ni}(\mathrm{II})$-induced peptide bond hydrolysis that occurs at the N-terminal side of Ser or Thr residues in peptides, ${ }^{26-36}$ designed recombinant proteins ${ }^{37,38}$ and flexible regions of native proteins ${ }^{37,39}$ bearing X-(Ser/Thr)$\mathrm{X}$-His-X sequences ( $\mathrm{X}$ being any amino acid except for Cys or Pro before or after Ser/Thr). The method found application in the affinity tag removal from fusion proteins by Ni(II) ions. ${ }^{37,38}$ 
The cleavage is site specific and sequence selective making this method unique among other approaches using metal ions. ${ }^{31,37,40}$ The molecular mechanism of this reaction was proposed earlier $^{31,35}$ and is depicted in Fig. S1 (ESI $\dagger$ ). The formation of a square planar Ni(II) complex is strictly required for the reaction: it contains the $\mathrm{Ni}$ (II) ion bound to the imidazole nitrogen of the His residue and three preceding amide nitrogens. ${ }^{31,35}$

Various human transcription factors contain potential Ni(II) cleavage sites within their $\mathrm{Cys}_{2} \mathrm{His}_{2} \mathrm{ZF}$ units. The 27 amino acid long peptide, representing the $3^{\text {rd }} \mathrm{ZF}$ unit of the Sp1 human transcription factor was shown to be cleaved by $\mathrm{Ni}$ (II) ions even though the His residue crucial for the reaction was initially complexed to the structural $\mathrm{Zn}$ (II) ion. ${ }^{32}$ The $\mathrm{Zn}$ (II) binding site and the structure of the ZF unit was abolished in the reaction. Naturally occurring Ni(II)-cleavage sites, which are present in nearly $25 \%$ of human $\mathrm{Cys}_{2} \mathrm{His}_{2} \mathrm{ZF}$ sequences ${ }^{32}$ can thus be considered potentially susceptible to hydrolysis upon the exposure to $\mathrm{Ni}(\mathrm{II})$ ions naturally present in human tissues. ${ }^{41}$ Nickel is absorbed through the diet, skin, lungs and then taken up by cells. $^{42,43}$ By analogy with the hydrolytic cleavage of histone $\mathrm{H} 2 \mathrm{~A}$ observed in Ni(II)-exposed cell cultures, endogenous nickel present in human cells may damage ZFs as part of its toxicity.

The knowledge, summarized above, inspired us to challenge sequence specific $\mathrm{Ni}$ (II)-induced peptide bond cleavage within a complex metalloprotein such as a $\mathrm{Cys}_{2} \mathrm{His}_{2}$-type classical ZF array consisting of three ZF units and also possessing a Ni(II)-cleavable $\mathrm{N}$-terminal deka-His fusion tag. Our aim was to verify that the binding of $\mathrm{Zn}$ (II) ions is unaffected by the presence of the Ni(II) ions in the uncleaved finger units, i.e. they are not replaced by $\mathrm{Ni}(\mathrm{II})$ ions and the oxidation of cysteines in the binding sites is not catalysed by $\mathrm{Ni}$ (II) ions. We analysed and optimized the cleavage of two ZF proteins by Ni(II) ions at a single peptide bond between the protein and the affinity tag, and investigated the structural integrity, as well as the $\mathrm{Zn}$ (II) and DNA binding properties of the products by spectrometric and electrophoretic methods.

\section{Materials and methods}

\section{Gene construction}

Two ZF proteins, denoted by $\mathrm{P}-1 \mathrm{MEY}$ and $\mathrm{P}-1 \mathrm{MEY} \#$ were investigated, both consisting of three ZF units. The P-1MEY protein is similar to that included in the ZF protein/DNA crystal structure, with $1 \mathrm{MEY} \mathrm{PDB}$ code,${ }^{44}$ and the $\mathrm{P}-1 \mathrm{MEY} \# \mathrm{ZF}$ protein is its modified version as described below. The gene of the P-1MEY protein was ordered as a full length DNA with a stop codon (IDT Japan Ltd) and ligated into a pET-16b vector between the NdeI and BamHI sites. The gene of the P-1MEY\# protein was constructed starting from the above DNA sequence by the modified QuikChange ${ }^{\mathrm{TM}}$ site-directed mutagenesis method (QCM, Stratagene, La Jolla, CA) using the following primers:

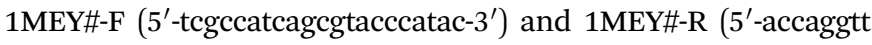
atcgetgcgggaaaatgacttc- $3^{\prime}$ ) according to Scheme S1 (ESI $\dagger$ ). Consequently, a His was replaced with Asn (H99N) and a Ser with Val (S101V). After the amplification of the DNA with KOD-FX DNA polymerase (TOYOBO, Japan), the resulted DNA fragments were treated by $\mathrm{T} 4$ polynucleotide kinase (TOYOBO, Japan) and T4 ligase in the ligation high premix (TOYOBO, Japan). DH5 $\alpha$ cells were transformed with the resulted plasmid, and after the DNA purification the success of the mutagenesis was verified by a standard sequencing procedure.

\section{Protein expression and purification}

The P-1MEY and P-1MEY\# proteins were expressed in BL21 (DE3) E. coli cells, which were cultured to OD of $c a$. 0.3 , then the protein expression was induced by $0.2 \mathrm{mM}$ IPTG at $20{ }^{\circ} \mathrm{C}$ for 18 hours. Cells were collected and resuspended in a buffer containing $500 \mathrm{mM} \mathrm{NaCl}, 100 \mathrm{mM}$ HEPES (pH 8.2), and $10 \mathrm{mM}$ imidazole, and then sonicated. The pET-16b-P-1MEY and pET-16b-P-1MEY\# plasmids permitted introduction of the $\mathrm{N}$-terminal deka-His tag and thus, the expressed proteins were subjected to Ni(II)-affinity chromatography as the main purification step. Applying an imidazole concentration gradient in the eluent, most of the target proteins were obtained at $300 \mathrm{mM}$ imidazole as shown in Fig. S2a (ESI $\dagger$ ). The Zn(II) load of the ZF proteins was verified by EDTA titration of the ZF proteins monitored by circular dichroism spectroscopy (Fig. S2b, ESI $\dagger$ ). The $\mathrm{Zn}$ (II) contents of the purified ZF proteins were $3.0 \pm 0.2$ equivalents/protein molecule.

\section{Protein hydrolysis by Ni(II) ions}

30-40 $\mu \mathrm{M}$ P-1MEY or P-1MEY\# proteins were incubated with $400 \mu \mathrm{M} \mathrm{Ni(II)} \mathrm{(} 10$-fold molar excess) in a $100 \mathrm{mM}$ HEPES buffer with such an addition of $\mathrm{Zn}$ (II) that a $10-100 \mu \mathrm{M}$ final concentration of $\mathrm{Zn}$ (II) ions in excess of the protein remained in solution. The conditions of the hydrolytic experiments varied between $50{ }^{\circ} \mathrm{C}, \mathrm{pH} 8.2$ and $37{ }^{\circ} \mathrm{C}, \mathrm{pH} 7.4$ (i.e. close to physiological conditions). Control reaction mixtures without $\mathrm{Ni(II)}$ were incubated for 72 hours under the same conditions. All samples were prepared and then incubated in low adsorption $1.5 \mathrm{ml}$ tubes (LowBind, Eppendorf), using a thermoblock (TB-941U, JW Electronic).

$20 \mu \mathrm{l}$ samples were collected from reaction mixtures at given time points and the reactions were terminated by acidification (2\% TFA), as performed and justified before. ${ }^{35}$ Samples were analysed by polyacrylamide gel-electrophoresis (Tricine-SDS$\mathrm{PAGE}^{45}$ ), and in parallel by HPLC (Breeze, Waters) using an ACE C18 analytical column. The eluting solvent A was $0.1 \%$ TFA/water and solvent B was $0.1 \%$ TFA/90\% acetonitrile.

\section{Electrospray ionization mass spectrometry (ESI-MS)}

The samples investigated by ESI-MS (Premier, Q-Tof1, Waters) were either obtained from the HPLC separation of the cleavage products as described above (P-1MEY), or taken directly from the reaction mixture ( $\mathrm{pH} 8.2$ ) with or without the sample acidification to $\mathrm{pH}<4.0$ ( $\mathrm{P}-1 \mathrm{MEY} \#)$. The samples were analysed following a buffer exchange (to $100 \mathrm{mM} \mathrm{NH}_{4} \mathrm{HCO}_{3}, \mathrm{pH}$ 8.1) or desalting on a RP-C18 pre-column (Waters).

\section{Circular dichroism (CD) measurements}

CD measurements were performed on a JASCO J-815 spectropolarimeter in quartz cuvettes $(d=2 \mathrm{~mm}$ or $0.1 \mathrm{~mm})$. The spectra were recorded in the $180-300 \mathrm{~nm}$ range, using $0.5 \mathrm{~nm}$ resolution, 
$2 \mathrm{~s}$ response time, and scanning speed of $20 \mathrm{~nm} \mathrm{~min}^{-1}$. The samples were taken directly from the hydrolytic reaction mixture at the beginning and after the termination of the reaction. The solvent was exchanged to $5 \mathrm{mM}$ phosphate buffer $(\mathrm{pH} 7.4)$ prior to the CD experiment using an Amicon Ultra-0.5 Centrifugal Filter Unit with Ultracel-3 membrane having a nominal molecular weight limit of $3 \mathrm{kDa}$.

\section{Electrophoretic mobility shift assay (EMSA)}

The $1 \mathrm{MEY}+2 \mathrm{bp}$ oligonucleotide probe of the sequence $5^{\prime}$-CG TTCTGCCTCACTTTTGTGAGGCAGAACG- ${ }^{\prime}$, which included the $1 \mathrm{MEY}$ target sequence (underlined) and the ZFP\#2+2bp probe of the sequence $5^{\prime}$-CGGGGATAGGCACTTTTGTGCCTATCCCCG-3' were used for EMSA experiments. These oligonucleotides were labeled with $\left[\gamma^{-32} \mathrm{P}\right]$ ATP by T4 polynucleotide kinase (TOYOBO). The labeled oligonucleotides were self-annealed, to yield the double strand sequence stabilized by the TTTT loop, and then purified from native PAGE, and used as probes. EMSA experiments were performed in $10 \mu \mathrm{l}$ of a $60 \mathrm{mM}$ HEPES buffer, $\mathrm{pH}$ 8.2, containing $10 \%$ (V/V) glycerol, $45 \mathrm{mM} \mathrm{NaCl},{ }^{32}$ P-end-labeled probe (15 fmol) and P-1MEY or P-1MEY\# protein at a concentration giving rise to a protein excess between 0 and 100 fold, as indicated in Fig. 1. The reaction mixtures were separated on a $6 \%(\mathrm{~m} / \mathrm{V})$ polyacrylamide gel containing $12.5 \mathrm{mM}$ Tris buffer and $96 \mathrm{mM}$ glycine. Radiolabeled probes were visualized by a BAS2000 imager. Further EMSA experiments were carried out with a DNA probe including four tandem copies (underlined) of the favourable $1 \mathrm{MEY}$ binding sequence. It was constructed by the annealing and subsequent prolongation of the following deoxy-oligonucletide primers to yield a 72 bp DNA:

5'-GGCGAATTCGAGGCAGAATGCTTATTCTGCCTCGAGCTCG AG-3'

5'-GGCGAATTCGAGGCAGAATAAGCATTCTGCCTCGAGCTCG AG-3'. The DNA samples $\left(c_{\text {final }}=4.0 \mu \mathrm{M}\right)$ were incubated with increasing amounts of the Ni(II)-cleaved P-1MEY\# ZF protein from $1: 1$ to $1: 4$ molar ratio at $\mathrm{pH} 7.4$ in a $100 \mathrm{mM}$ HEPES buffer.
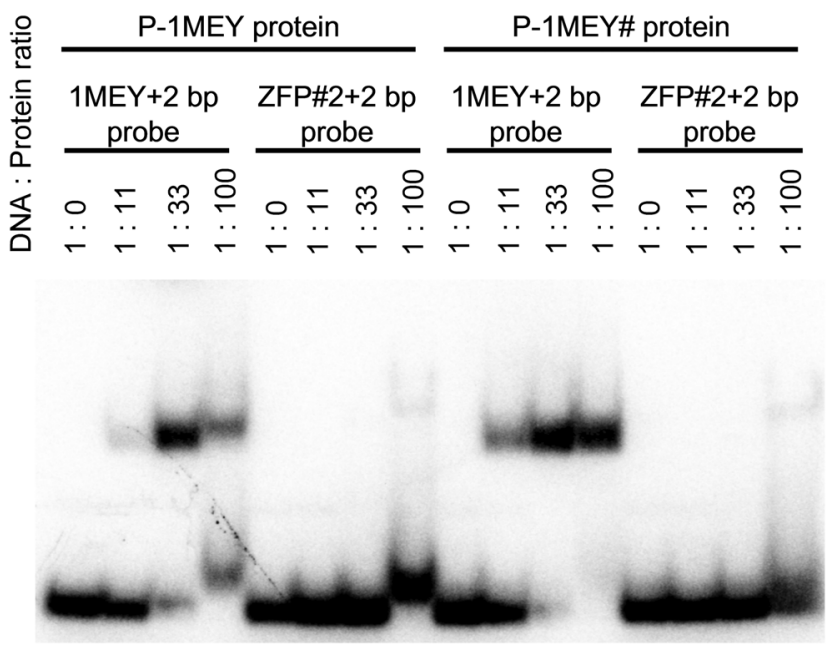

Fig. 1 Electrophoretic mobility shift assay of the P-1MEY and P-1MEY\# proteins with the specific $(1 \mathrm{MEY}+2 \mathrm{bp})$ and non-specific $(Z F P \# 2+2 \mathrm{bp})$ DNA probes.
The reaction mixtures were separated on a $2 \%(\mathrm{~m} / \mathrm{V})$ agarose gel and the DNA was visualized by the intercalated ethidium ion fluorescence using an UviDoc gel documentation system.

\section{Results and discussion}

\section{Choice and redesign of the $\mathrm{ZF}$ protein}

The P-1MEY ZF protein sequence is based on the consensus sequence CP-1 derived by Berg et al., ${ }^{46}$ and confirmed by a recent study, ${ }^{47}$ with the exception of the amino acids responsible for DNA recognition. It is a well studied protein suitable for our model cleavage experiments. The sequence was derived from a $\mathrm{ZF}$ protein (denoted as P-1MEY-PDB) previously structurally characterized in the complex with its cognate DNA (PDB code $1 \mathrm{MEY}){ }^{44}$ The amino acid sequences of the P-1MEY and mutant P-1MEY\# proteins investigated by us are aligned to the P-1MEY-PDB protein in Scheme 1. The core sequence of P-1MEY responsible for the functional structure and DNA recognition was kept intact. The sequence was modified here by the deka-His tag at the N-terminus for the purpose of affinity purification. Further amino acids, following the affinity tag sequence were encoded by the pET-16b plasmid: SSGH contains the underlined Ni(II)-sensitive sequence and IEGR is the Factor Xa protease (NEB) recognition sequence. Short extensions (additional amino acids compared to the $\mathrm{P}-1 \mathrm{MEY}-\mathrm{PDB}$ ) at both termini of the $\mathrm{P}-1 \mathrm{MEY}$ protein sequence (see Scheme 1) can be derived from the consensus sequence as they are found in the Zinc Finger Tools program used for protein redesign (vide infra). ${ }^{13}$

$\mathrm{P}-1 \mathrm{MEY}$ contains three $\mathrm{X}(\mathrm{S} / \mathrm{T}) \mathrm{XHX}$ sequence motifs that can undergo hydrolytic cleavage upon Ni(II)-binding. Two of them are located close to each other within the DNA recognition region of the $3^{\text {rd }}$ ZF unit (similarly to the $3^{\text {rd }}$ ZF unit of Sp1 - Scheme 1), while the third sequence is located between the $\mathrm{N}$-terminal deka-His tag and the $\mathrm{ZF}$ protein sequence. Based on the experiments with the Sp1 C-terminal peptide ${ }^{32}$ the possible $\mathrm{Ni}(\mathrm{II})$-dependent hydrolysis within the $3^{\text {rd }} \mathrm{ZF}$ unit of P-1MEY may be expected to affect the properties of this finger. Therefore, we redesigned $\mathrm{P}-1 \mathrm{MEY} \mathrm{ZF}$ protein into $\mathrm{P}-1 \mathrm{MEY}$ \# with a single $\mathrm{Ni}(\mathrm{II})$-sensitive sequence at the $\mathrm{N}$-terminus, by editing out the hydrolysable sequences in the $3^{\text {rd }}$ finger.

Since the necessary substitutions fall within the DNA recognition sequence, the Zinc Finger Tools program ${ }^{13}$ was utilized to maintain the DNA binding specificity. For the target DNA sequence derived from the $1 \mathrm{MEY} / \mathrm{DNA}$ structure, ${ }^{44}$ the program yielded a $\mathrm{ZF}$ protein sequence differing at various sites from the original one (Zinc Finger Tools sequence in Scheme 1). To obtain the P-1MEY\# protein we introduced only the minimal changes limited to the $3^{\text {rd }} \mathrm{ZF}$ unit involving the His to Asn (H99N) and Ser to Val (S101V) substitutions (Scheme 1; see the Materials and methods section for details).

The DNA-binding specificity was maintained in the redesigned ZF protein

The DNA binding properties of the P-1MEY-PDB ZF protein were previously studied and the 5'-GAGGCAGAA-3' DNA sequence included in the $1 \mathrm{MEY}$ crystal structure was considered as a 

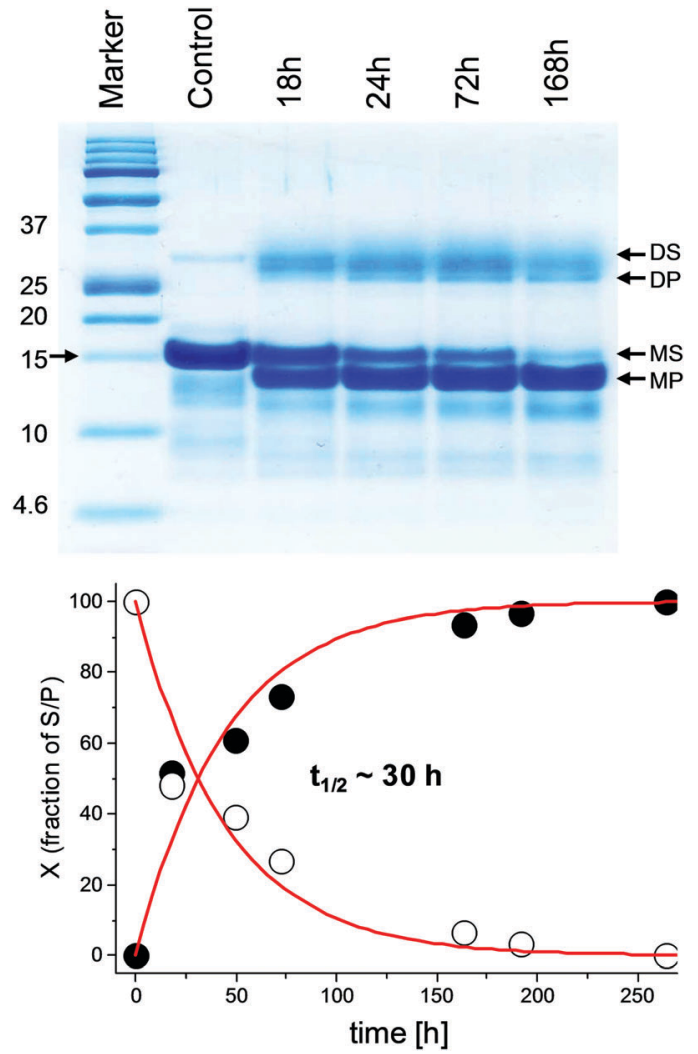

Fig. 2 Top: The electrophoretic analysis of the $\mathrm{Ni}($ II)-dependent hydrolysis of P-1MEY\# ZF protein at $37{ }^{\circ} \mathrm{C}$ and $\mathrm{pH}$ 8.2; incubation times in hours (h), $\mathrm{S}$ - substrate, $\mathrm{P}$ - product; $\mathrm{D}$ and $\mathrm{M}$ stand for the dimer and monomer, respectively. Bottom: Kinetic plots of substrate formation (filled circles) and product depletion (empty circles) in the hydrolysis reaction based on the densitometric analysis of the Tricine-SDS-PAGE image considering only the bands of the monomeric protein fractions. The red line represents the fitting to the $1^{\text {st }}$ order rate law.

converted into a single high molecular weight hydrolysis product (Fig. 2).

According to the kinetic analysis, the hydrolysis of the P-1MEY\# mutant protein occurred more slowly than that of the P-1MEY $\left(t_{1 / 2}=30 \mathrm{~h} v s .14 \mathrm{~h}\right.$ at $37^{\circ} \mathrm{C}$ and $\mathrm{pH}$ 8.2). The control experiment without the $\mathrm{Ni}$ (II) ions revealed only a marginal degradation of the protein after $72 \mathrm{~h}$ of incubation at the elevated temperature and $\mathrm{pH}$.

The Ni(II)-induced hydrolysis of P-1MEY and P-1MEY\# ZFs was investigated at 50 or $37^{\circ} \mathrm{C}$ and pH 8.2 or 7.4 to demonstrate the significant effect of the temperature and $\mathrm{pH}$ on the reaction rate. The hydrolysis experiments repeated under physiologicallike conditions at $37^{\circ} \mathrm{C}$ and $\mathrm{pH} 7.4$ indicated that the reactivity pattern was maintained, although the reaction rate decreased significantly for both P-1MEY and P-1MEY\#. The densitometric results obtained from SDS PAGE gel analysis are shown in Fig. S6 $(\mathrm{ESI} \dagger)$. These data were used to calculate reaction rate constants. The comparison of $t_{1 / 2}$ values in the $1^{\text {st }}$ order kinetic approximation revealed their strong $\mathrm{pH}$ dependence. We observed a 9-fold increase of the reaction rate between $\mathrm{pH} 7.4$ and 8.2 at $37{ }^{\circ} \mathrm{C}\left(t_{1 / 2}\right.$ of $\sim 11 \mathrm{~d}$, and $\sim 30 \mathrm{~h}$, respectively). The increase of the temperature from $37{ }^{\circ} \mathrm{C}$ to $50{ }^{\circ} \mathrm{C}$ resulted in a further acceleration
Table 1 Products of Ni(I)-assisted hydrolysis of P-1MEY and P-1MEY\# identified by ESI-MS. SXH indicates the cleavage sites

\begin{tabular}{llll}
\hline Protein & Cleavage site & $\begin{array}{l}M_{\mathrm{W}} \text { experimental } \\
(\mathrm{Da})\end{array}$ & $\begin{array}{l}M_{\mathrm{W}} \text { calculated (Da) } \\
\text { all-SS/all-SH }\end{array}$ \\
\hline P-1MEY $^{a}$ & - & 13012 & $13006.3 / 13012.3$ \\
& SRH (L) & $11500^{c}$ & $11500.6 / 11506.6$ \\
& SGH (L) & $11496^{d}$ & $11490.7 / 11496.7$ \\
& SGH + SRH (L) & $11743^{e}$ & 11743.5 \\
& SGH + SDH (L) & 9986 & $9985.1 / 9991.1$ \\
& & $9536^{f}$ & $9532.6 / 9538.6$ \\
& SRH (S) & $9720^{g}$ & $9532.6 / 9538.6$ \\
& SGH (S) & 1524 & 9722,1 \\
P-1MEY\# & SDH (S) & n.d. & 1523.6 \\
& SGH (L) & 13001 & 1533.5 \\
& SGH (L) & $11487^{d}$ & 1976.1 \\
& & $11733^{e}$ & 13001.3 \\
& & 11485.8 \\
& & 11732.6
\end{tabular}

${ }^{a}$ Separation of the P-1MEY cleavage products by HPLC was performed under acidic conditions thus, the products did not contain complexed metal ions. ${ }^{b}(\mathrm{~S})$ and (L) denote the small and large protein products of the hydrolysis at each site. n.d., not detected. For the sequences see Table S1 (ESI). ${ }^{c}$ HPLC peak broadened due to the presence of various oxidation products. The comparison of the calculated and measured masses of the central large $(\mathrm{L})$ protein portions yielded a 6 Da difference, corresponding to oxidation of Cys residues to disulfides. ${ }^{d}$ No oxidation products were detected when the sample was directly taken from the reaction mixture and immediately acidified. ${ }^{e}$ The protein sample was not acidified. The calculated mass reflected the coordination of $3 \times \mathrm{Zn}$ (II) and $1 \times \mathrm{Ni}(\mathrm{II})$ ions. ${ }^{f}$ Oxidation of Cys residues within the destroyed finger unit was detected when the sample was directly taken from the reaction mixture and immediately acidified. ${ }^{g}$ The protein sample was not acidified. The calculated mass reflected the coordination of $2 \times \mathrm{Zn}$ (II) and $1 \times \mathrm{Ni}(\mathrm{II})$ ions. Oxidation of cysteines within the destroyed finger unit was detected.

of the reaction rate $\left(t_{1 / 2} \sim 7.5 \mathrm{~h}\right)$. The $\mathrm{pH}$ dependence of the $1^{\text {st }}$ order rate constant for the $\mathrm{Ni}$ (II)-assisted hydrolysis reaction has a sigmoidal shape. The reaction rate is maximal at $\mathrm{pH}$ above pH 8.2, where the square planar $(4 \mathrm{~N})$ complex predominates. At lower $\mathrm{pH}(\mathrm{pH} 7.4)$ the extent of the formation of the active $4 \mathrm{~N}$ complex is much lower: $20-80$ times less, compared to $\mathrm{pH} 8 . .^{31,52,53}$

\section{Verification of the cleavage specificity and binding of the metal ions by MS}

The resolution of the gel electrophoresis is not sufficient to precisely identify the hydrolytic cleavage sites. Therefore, we analysed the reaction mixtures by ESI-MS. The experimentally determined masses of the substrate proteins and their Ni(II)-hydrolysis products agreed well with the theoretical predictions. Among the P-1MEY products we identified short GHHHHHHHHHHS

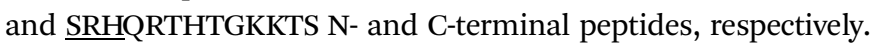
The peptide resulting from the cleavage at the $\underline{\mathrm{SDH}}$ site, SDHLSRHQRTHTGKKTS, was not detected as the cleavage within the $\underline{\mathrm{SRH}}$ sequence was much faster than that at $\mathrm{SDH}$, as predicted. ${ }^{32}$ However, the SDHL tetrapeptide was detected, confirming that both SDH and the SRH cleavage sites were hydrolytically active. The protein product after cleavage at both SGH and SDH sites was also found (Table 1 and Table S1, ESI $\dagger$ ). These data revealed that the three Ni(II)-susceptible sequences exerted different activities during the reaction with the $\mathrm{Ni}$ (II) 
ion. The hydrolysis at the SDH site was the least favorable one, consistently with previous studies on model peptides. ${ }^{30-32}$ The mass of the final P-1MEY product of 9720 Da reflects the coordination of $2 \times \mathrm{Zn}$ (II) and $1 \times \mathrm{Ni}$ (II) ions and the oxidation of cysteines within the destroyed $3^{\text {rd }} \mathrm{ZF}$ unit, which lost the $\mathrm{Zn}$ (II) ion binding ability after hydrolysis.

The ESI MS analysis of the P-1MEY\# reaction products at various $\mathrm{pH}$ confirmed the identity of the cleaved protein and its metal binding status. The mass obtained under acidic conditions corresponded well to that of the cleaved apoprotein. The mass of the hydrolyzed P-1MEY\# protein in a buffered solution was 11733 Da (Table S1, ESI $\dagger$ ). As the calculated mass of the apoprotein is $11485.8 \mathrm{Da}$, it proves the coordination of three $\mathrm{Zn}$ (II) ions within the $\mathrm{ZF}$ units and a Ni(II) ion at the $\mathrm{N}$-terminal ATCUN motif formed by the cleavage reaction (the calculated mass of the holoprotein is $11733.6 \mathrm{Da}$ ). The thiolate oxidation detected within the $3^{\text {rd }}$ finger of the original P-1MEY was not observed here due to the fact that the $\mathrm{Zn}$ (II) binding sites of the redesigned $\mathrm{P}-1 \mathrm{MEY} \#$ protein remained intact during the hydrolytic process.

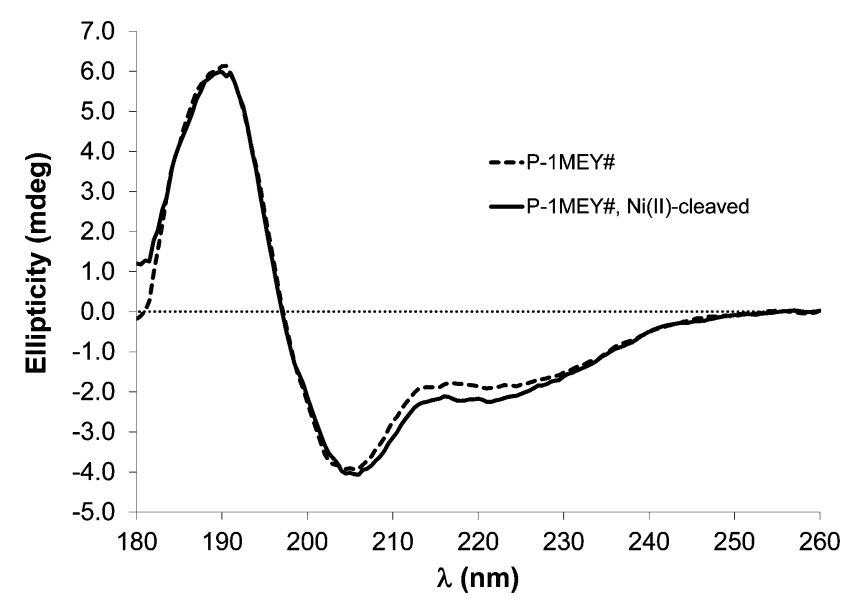

Fig. 3 Circular dichroism spectra of the P-1MEY\# protein and its $\mathrm{Ni}(\mathrm{II})$-cleaved product in $5 \mathrm{mM}$ phosphate buffer ( $\mathrm{pH}$ 7.4) at $50 \mu \mathrm{M}$ protein concentration in a $0.1 \mathrm{~mm}$ quartz cell.
The functional structure is maintained in the $\mathrm{Ni}(\mathrm{II})$-complexed P-1MEY\# cleavage product

Circular dichroism spectra of P-1MEY\# were recorded before and after the $\mathrm{Ni}(\mathrm{II})$-induced hydrolysis, which resulted in the $\mathrm{N}$-terminal deka-His tag removal. The comparison of these confirmed the preservation of the spectral pattern characteristic for the folded solution structure of $\mathrm{a} \mathrm{Cys}_{2} \mathrm{His}_{2} \mathrm{ZF}$ unit ${ }^{18,54}$ in the cleavage product (Fig. 3), even though the reaction was carried out at harsh conditions $\left(50{ }^{\circ} \mathrm{C}\right.$ and $\left.\mathrm{pH} 8.2\right)$, and the buffer was exchanged before the CD measurement.

The CD results further confirmed that unwanted modifications such as the cleavage at non-specific sites, removal of $\mathrm{Zn}$ (II) ions or oxidative damage of the protein did not occur to a detectable extent in the modified P-1MEY\# protein. The slight increase of the $\mathrm{CD}$ intensity should be the consequence of the removal of the short disordered N-terminal His-tag (GHHHHHHHHHHS). The CD spectrum of the cleaved P-1MEY protein (Fig. S7, ESI + ) is practically identical to that of the intact $\mathrm{P}-1 \mathrm{MEY}$. This suggests that the ordering effect of the His-tag removal and the disordering effect of the remnant peptide sequence after the cleavage of the $3^{\text {rd }}$ finger unit partially compensate for each other, and that the structure of the two uncleaved ZF units was maintained during the hydrolytic reaction in good agreement with the MS results. The consequences of editing out the cleavage sites from the DNA recognition region of $\mathrm{P}-1 \mathrm{MEY}$ in the $\mathrm{Ni}(\mathrm{II})$-induced hydrolytic peptide bond cleavage reaction are manifested in Fig. 4.

The question whether the Ni(II)-cleaved P-1MEY\# is able to recognize its cognate DNA was investigated by EMSA. The band of the DNA molecule including four copies of the ZF recognition site was already shifted in agarose gel upon addition of one molar equivalent of the protein (Fig. 5). By increasing the protein excess a second distinct shifted band appeared due to the binding of one or more further protein molecules. At a fourfold excess of the protein only the second band was observed. A smear was present to a small extent attributed to minor non-specific binding - natural for all ZF protein as a consequence of the electrostatic component of their interactions with DNA. Similar phenomena were observed with intact $\mathrm{P}-1 \mathrm{MEY}$, indicating that both proteins can interact with the favourable DNA sequences equally effectively.

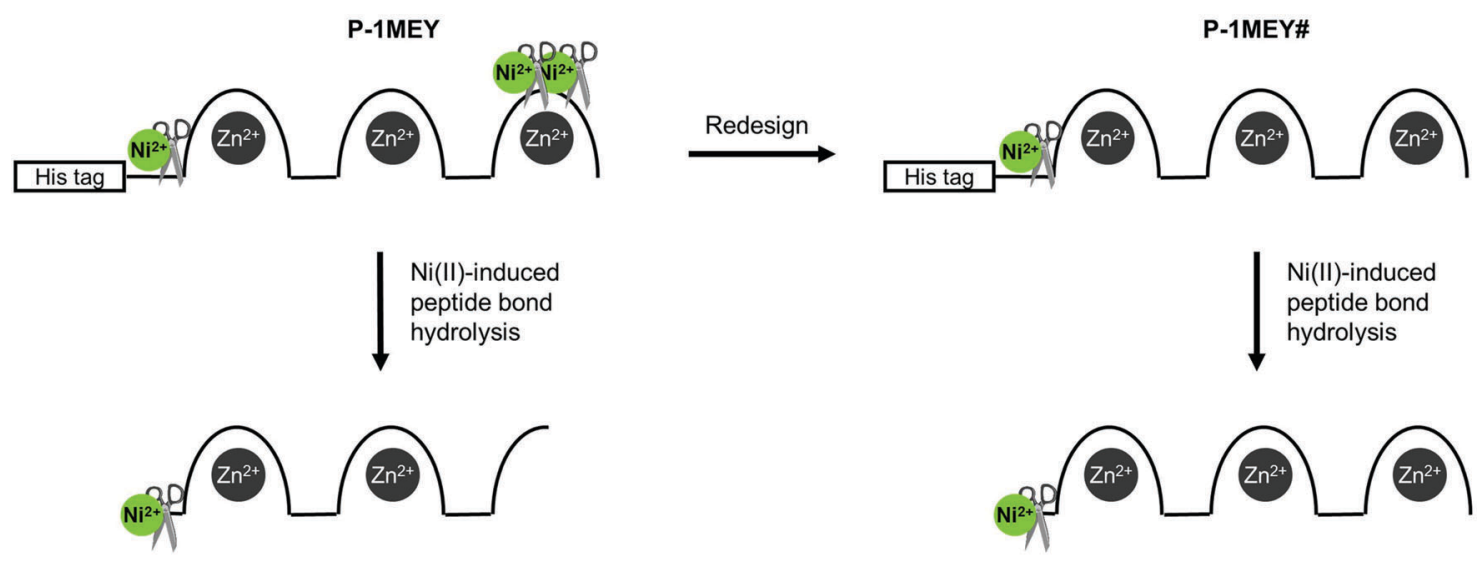

Fig. 4 Schematic representation of the $\mathrm{Ni}(॥)$-induced cleavage of P-1MEY and the redesigned P-1MEY\# ZF proteins. 


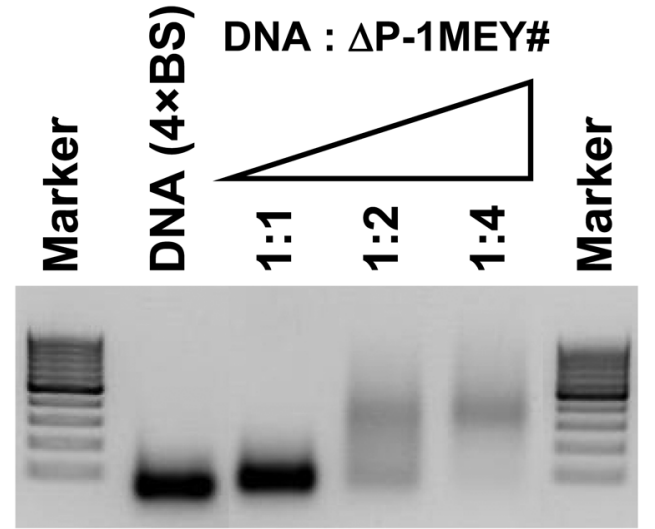

Fig. 5 DNA binding of the Ni(I)-cleaved P-1MEY\# ZF protein (denoted by $\triangle \mathrm{P}-1 \mathrm{MEY} \#)$. A short double strand DNA including four tandem segments of the favourable $5^{\prime}$-GAGGCAGAA-3' sequence was applied in the EMSA experiments. The intensity decrease at higher protein to DNA ratios is presumably due to the impaired ability of the ethidium ion to bind the protein-loaded DNA.

\section{Conclusion}

We have tested for the first time the possibility of the specific peptide bond hydrolysis induced by Ni(II) ions within two complex His-tagged ZF metalloproteins without compromising the original metal ion binding sites. The hydrolytic cleavage of the two potential Ni(II)-cleavage sites within the $3^{\text {rd }}$ finger was not hindered by the presence of $\mathrm{Zn}$ (II) ions, but concomitantly it abolished the $\mathrm{Zn}$ (II) binding site, resulting in loss of the functional structure of this finger. Such partial cleavage of a ZF type protein may lead to altered DNA binding causing unwanted side-effects in cells. Under the applied conditions the deka-His affinity tag did not interfere with the hydrolytic peptide bond cleavage.

We redesigned the P-1MEY protein to edit out the naturally occurring $\mathrm{Ni}$ (II) cleavage sites in the $3^{\text {rd }}$ ZF unit and to obtain a single $\mathrm{N}$-terminal $\mathrm{Ni}(\mathrm{II})$-catalytic site between the $\mathrm{N}$-terminal His-tag and the ZF protein sequence. The Zinc Finger Tools program was applied to design sequence changes without affecting the DNA binding specificity. We confirmed experimentally that the P-1MEY\# protein maintained the $\mathrm{Zn}(\mathrm{II})$ and Ni(II)-binding ability and a functional solution structure after the Ni(II)induced protein hydrolysis. This is crucial for any subsequent applications.

Importantly, the $\mathrm{Ni}(\mathrm{II})$ ion remains coordinated to the (Ser/Thr)$\mathrm{X}$-His motif in the C-terminal cleavage product. Such peptide sequence, characterized by the presence of a His residue in position 3 (referred to as ATCUN motif) provides strong $\mathrm{Cu}$ (II) or Ni(II) binding and was shown to cleave DNA in the presence of peroxides. ${ }^{55,56}$ Functionalization with DNA-binding agents can enhance the efficiency or the selectivity of this reaction, ${ }^{23,55,57-64}$ and may provide a chance for future treatment of $\mathrm{Ni}(\mathrm{II})$-dependent cancer utilizing the abundant $\mathrm{Ni}(\mathrm{II})$ ions present there already. ${ }^{65-71}$

The advantage of our approach compared to previous reports is that the ATCUN site of the ZF protein is initially masked by

the $\mathrm{Ni}(\mathrm{II})$ sensitive sequence, and can be activated and regulated by the addition of $\mathrm{Ni}(\mathrm{II})$ ions, temperature jump or $\mathrm{pH}$ jump (as the rate of the peptide bond cleavage itself is strictly dependent on these three factors). ${ }^{30-32,37-39}$ Furthermore, the Ni(II) induced peptide-bond hydrolysis can be applied for the removal of any fusion proteins (such as affinity tags, inhibitory or activating domains) from sensitive ZF metalloproteins. Thereby it provides a chance for simple regulation and replacement of the expensive specific protease enzymes. The N-terminal metal-binding site may also promote the application of zinc fingers and eventually their fusion variants as specific carriers of drugs or sensors in their ternary complexes. Recently it has been reported that the ATCUN motif can improve bioactivity of antimicrobial peptides. $^{72}$

Zinc finger proteins are potential biotechnological tools for specific gene recognition and manipulation. Although the recent competitive TALE and especially the CRISPR technologies prevail this field, ${ }^{73-75} \mathrm{ZF}$ protein based factors may still be attractive choice for eukaryotic applications because of their complex protein-DNA interface (the complexity of intra- and inter-finger interactions allows one for discrimination between similar targets), small size, human origin, as well as their low antigenicity. This is reflected in a number of recent publications. ${ }^{65,76-78}$ In addition the method described above can be generally applied for any engineered protein, and by optimizing the $\mathrm{Ni}(\mathrm{II})$-induced protein hydrolysis to be significantly accelerated it may significantly contribute to this field.

\section{Abbreviations}

$\left[\gamma^{32} \mathrm{P}\right] \mathrm{ATP}$

1MEY\#-F

1MEY\#-R

$1 \mathrm{MEY}$

ATCUN

BamHI

BL21 (DE3)

CD

CP-1

CRISPR

$\mathrm{Cys}_{2} \mathrm{His}_{2}$

DH5 $\alpha$

EMSA
Adenosine triphosphate labelled with radioactive phosphorus.

Forward primer used during QCM to create the gene of $\mathrm{P}-1 \mathrm{MEY} \#$ protein.

Reverse primer used during QCM to create the gene of $\mathrm{P}-1 \mathrm{MEY} \#$ protein.

The PDB code of a ZF protein in complex with its specific DNA.

Amino terminal copper and nickel binding motif contains a His in the third position from the $\mathrm{N}$-terminal end of the peptide/protein.

Type II restriction endonuclease isolated from Bacillus amyloliquefaciens.

Chemically competent $E$. coli cells suitable for protein expression.

Circular dichroism.

Consensus peptide 1 .

Clustered regularly interspaced short palindromic repeats.

Most commonly occurring Zn(II) binding site donor set in ZF units.

Competent E. coli cells for cloning applications.

Electrophoretic mobility shift assay. 
ESI-MS

Factor Xa

FokI

H2A

HEPES

His-tag

HPLC

IDT

IEGR

IPTG

KOD-FX

native PAGE

NdeI

NEB

OD

P-1MEY\#

P-1MEY

P-1MEY-PDB

PDB

pET-16b

pET-16b-P-1MEY\#

pET-16b-P-1MEY

QuikChange $^{\mathrm{TM}}$ (QCM) Site-directed in vitro mutagenesis

Sp1

TALE

TFA

Tricine-SDS-PAGE

Tris method.

Electron spray ionisation mass spectro- $\quad$ ZF unit metry.

Protease, which recognises IEGR amino acid sequence and cleaves after the arginine.

Restriction endonuclease derived from

Flavobacterium okeanokoites.

Histone protein involved in the structure of chromatin in eukaryotic cells.

4-(2-Hydroxyethyl)-1-piperazineethanesulfonic acid commonly used buffer in biochemistry and molecular biology.

A dekahistidine-tag is an amino acid motif in proteins that consists of ten histidine (His) residues. The His-tag makes it possible to purify the protein by $\mathrm{Ni}(\mathrm{II})$ affinity chromatography.

High-performance liquid chromatography. Integrated DNA technologies ${ }^{\circledR}$.

Ile-Glu-Gly-Arg amino acid sequence.

Isopropyl $\beta$-D-1-thiogalactopyranoside

DNA polymerase from Toyobo Life Science Department.

Native polyacrylamide gel electrophoresis. Type II restriction endonuclease isolated from Neisseria denitrificans.

New England Biolabs ${ }^{\circledR}$.

Optical density.

Modified P-1MEY protein.

ZF protein similar to the P-1MEY-PDB protein.

The ZF protein part of the $1 \mathrm{MEY}$ complex. (Protein Data Bank) library of crystal structure data of proteins and proteinDNA complexes.

Cloning/expression vector carrying an $\mathrm{N}$-terminal His·Tag ${ }^{\circledR}$ sequence followed by a Factor Xa site.

pET-16b plasmid containing the gene of $\mathrm{P}-1 \mathrm{MEY} \#$ protein.

pET-16b plasmid containing the gene of $\mathrm{P}-1 \mathrm{MEY}$ protein.

A ZF-based transcription factor known as Specificity Protein 1.

Transcription activator-like effectors proteins are secreted by Xanthomonas bacteria infecting various plant species. 2,2,2-Trifluoroacetic acid.

A tricine modified sodium-dodecyl-sulfate polyacrylamide gel electrophoresis method for protein separation.

Tris(hydroxymethyl)aminomethane commonly used buffer in biochemistry and molecular biology.

ZF
A peptide of $\sim 22-24$ amino acids, having a tetrahedral metal binding site within a $\beta \beta \alpha$ structure. Each unit recognises a three nucleobase sequence.

Zinc finger protein consisting of ZF units.

\section{Conflicts of interest}

There are no conflicts to declare.

\section{Acknowledgements}

This work was supported by Foundation for Polish Science TEAM 2009-4/1 program, co-financed by European Regional Development Fund resources within the framework of Operational Program Innovative Economy, by the Hungarian National Research, Development and Innovation Office (GINOP-2.3.2-15-2016-00038 and K_16/120130), and by collaboration of Hungarian and Polish Academies of Sciences (grants NKM-102//2016 and 2/2014-2016, respectively). The equipment used was sponsored in part by the Centre for Preclinical Research and Technology (CePT), a project co-sponsored by European Regional Development Fund and Innovative Economy, The National Cohesion Strategy of Poland. We thank Mr Jacek Olędzki for assistance with ESI-MS experiments.

\section{References}

1 J. Miller, A. D. McLachlan and A. Klug, EMBO J., 1985, 4, 1609-1614.

2 A. Klug, Annu. Rev. Biochem., 2010, 79, 213-231.

3 D. Jantz, B. T. Amann, G. J. Gatto and J. M. Berg, Chem. Rev., 2004, 104, 789-799.

4 Q. Liu, Z.-Q. Xia and C. C. Case, J. Biol. Chem., 2002, 277, 3850-3856.

5 B. Dreier, R. R. Beerli, D. J. Segal, J. D. Flippin and C. F. Barbas, III, J. Biol. Chem., 2001, 276, 29466-29478.

6 B. Dreier, R. P. Fuller, D. J. Segal, C. V. Lund, P. Blancafort, A. Huber, B. Koksch and C. F. Barbas III, J. Biol. Chem., 2005, 280, 35588-35597.

7 B. Dreier, D. J. Segal and C. F. Barbas III, J. Mol. Biol., 2000, 303, 489-502.

8 D. J. Segal, B. Dreier, R. R. Beerli and C. F. Barbas III, Proc. Natl. Acad. Sci. U. S. A., 1999, 96, 2758-2763.

9 K.-H. Bae, Y. D. Kwon, H.-C. Shin, M.-S. Hwang, E.-H. Ryu, K.-S. Park, H. Y. Yang, D.-K. Lee, Y. Lee, J. Park, H. S. Kwon, H.-W. Kim, B.-I. Yeh, H. W. Lee, S. H. Sohn, J. Yoon, W. Seol and J.-S. Kim, Nat. Biotechnol., 2003, 21, 275-280.

10 J. Liu and G. D. Stormo, Bioinformatics, 2008, 24, 1850-1857.

11 M. S. Bhakta and D. J. Segal, Methods Mol. Biol., 2010, 649, 3-30.

12 F. Fu and D. F. Voytas, Nucleic Acids Res., 2013, 41, D452-D455. 13 J. G. Mandell and C. F. Barbas III, Nucleic Acids Res., 2006, 34, W516-W523.

14 J. D. Sander, M. L. Maeder, D. Reyon, D. F. Voytas, J. K. Joung and D. Dobbs, Nucleic Acids Res., 2010, 38, W462-W468. 
15 T. Mino, T. Mori, Y. Aoyama and T. Sera, Arch. Virol., 2008, 153, 1291-1298.

16 M. G. Di Certo, N. Corbi, G. Strimpakos, A. Onori, S. Luvisetto, C. Severini, A. Guglielmotti, E. M. Batassa, C. Pisani, A. Floridi, B. Benassi, M. Fanciulli, A. Magrelli, E. Mattei and C. Passananti, Hum. Mol. Genet., 2010, 19, 752-760.

17 M. Imanishi, T. Nakaya, T. Morisaki, D. Noshiro, S. Futaki and Y. Sugiura, ChemBioChem, 2010, 11, 1653-1655.

18 A. Nomura and A. Okamoto, Chem. Commun., 2009, 1906-1908.

19 M. Papworth, P. Kolasinska and M. Minczuk, Gene, 2006, 366, 27-38.

20 A. J. Wood, T. W. Lo, B. Zeitler, C. S. Pickle, E. J. Ralston, A. H. Lee, R. Amora, J. C. Miller, E. Leung, X. Meng, L. Zhang, E. J. Rebar, P. D. Gregory, F. D. Urnov and B. J. Meyer, Science, 2011, 333, 307.

21 D. Carroll, Annu. Rev. Biochem., 2014, 83, 409-439.

22 M. Dhanasekaran, S. Negi and Y. Sugiura, Acc. Chem. Res., 2006, 39, 45-52.

23 M. Nagaoka, M. Hagihara, J. Kuwahara and Y. Sugiura, J. Am. Chem. Soc., 1994, 116, 4085-4086.

24 E. Németh, G. K. Schilli, G. Nagy, C. Hasenhindl, B. Gyurcsik and C. Oostenbrink, J. Comput.-Aided Mol. Des., 2014, 28, 841-850.

25 E. Németh, M. N. Asaka, K. Kato, Z. Fábián, C. Oostenbrink, H. E. M. Christensen, K. Nagata and B. Gyurcsik, ChemBioChem, 2018, 19, 66-75.

26 W. Bal, J. Lukszo, K. Bialkowski and K. S. Kasprzak, Chem. Res. Toxicol., 1998, 11, 1014-1023.

27 W. Bal, R. Liang, J. Lukszo, S.-H. Lee, M. Dizdaroglu and K. S. Kasprzak, Chem. Res. Toxicol., 2000, 13, 616-624.

28 M. Mylonas, A. Krezel, J. C. Plakatouras, N. Hadjiliadis and W. Bal, J. Chem. Soc., Dalton Trans., 2002, 4296-4306.

29 A. Krezel, M. Mylonas, E. Kopera and W. Bal, Acta Biochim. Pol., 2006, 53, 721-727.

30 A. Krezel, E. Kopera, A. M. Protas, J. Poznanski, A. WysłouchCieszynska and W. Bal, J. Am. Chem. Soc., 2010, 132, 3355-3366.

31 E. Kopera, A. Krezel, A. M. Protas, A. Belczyk, A. Bonna, A. Wyslouch-Cieszynska, J. Poznanski and W. Bal, Inorg. Chem., 2010, 49, 6636-6645.

32 E. Kurowska., J. Sasin-Kurowska, A. Bonna, M. Grynberg, J. Poznanski, L. Knizewski, K. Ginalski and W. Bal, Metallomics, 2011, 3, 1227-1231.

33 A. M. Protas, H. H. N. Ariani, A. Bonna, A. PolkowskaNowakowska, J. Poznanski and W. Bal, J. Inorg. Biochem., 2013, 127, 99-106.

34 H. H. N. Ariani, A. Polkowska-Nowakowska and W. Bal, Inorg. Chem., 2013, 52, 2422-2431.

35 E. I. Podobas, A. Bonna, A. Polkowska-Nowakowska and W. Bal, J. Inorg. Biochem., 2014, 136, 107-114.

36 N. Wezynfeld, K. Bossak, W. Goch, A. Bonna, W. Bal and T. Fraczyk, Chem. Res. Toxicol., 2014, 27, 1996-2009.

37 E. Kopera, A. Belczyk and W. Bal, PLoS One, 2012, 7, e36350.

38 E. Kopera, S. Krzywda, M. Lenarcic Živkovic, A. Dvornyk, B. Kłudkiewicz, K. Grzelak, I. Zhukov, W. Zagórski-Ostoja, M. Jaskólski and W. Bal, PLoS One, 2014, 9, e106936.

39 N. E. Wezynfeld, A. Bonna, W. Bal and T. Fraczyk, Metallomics, 2015, 7, 596-604.
40 N. E. Wezynfeld, T. Fraczyk and W. Bal, Coord. Chem. Rev., 2016, 327-328, 166-187.

41 W. Rezuke, J. Knight and F. Sunderman, Jr., Am. J. Ind. Med., 1987, 11, 419-426.

42 Occupational, Industrial, and Environmental Toxicology, ed. M. I. Greenberg, R. J. Hamilton, S. D. Phillips and G. J. McCluskey, Pennsylvania, Mosby, 2nd edn, 2003.

43 J. J. Hostynek and H. I. Maibach, Nickel and the skin: Absorption, Immunology, Epidemiology, and Metallurgy, CRC Press, Taylor and Francis Group, 2002, p. 158.

44 C. A. Kim and J. M. Berg, Nat. Struct. Biol., 1996, 3, 940-945.

45 H. Schägger, Nat. Protoc., 2006, 1, 16-22.

46 B. A. Krizek, B. T. Amann, V. J. Kilfoil, D. L. Merkle and J. M. Berg, J. Am. Chem. Soc., 1991, 113, 4518-4523.

47 A. N. Besold, L. R. Widger, F. Namuswe, J. L. Michalek, S. L. J. Michel and D. P. Goldberg, Mol. BioSyst., 2016, 12, 1183-1193.

48 A. Miloch and A. Krezel, Metallomics, 2014, 6, 2015-2024.

49 M. Nagaoka, J. Kuwahara and Y. Sugiura, Biochem. Biophys. Res. Commun., 1993, 194, 1515-1520.

50 U. Heinz, L. Hemmingsen, M. Kiefer and H.-W. Adolph, Chem. - Eur. J., 2009, 15, 7350-7358.

51 J. B. Mangrum, I. Zgani, S. D. Tsotsoros, Y. Qu and N. P. Farrell, Chem. Commun., 2013, 49, 6986-6988.

52 A. Belczyk-Ciesielska, I. A. Zawisza, M. Mital, A. Bonna and W. Bal, Inorg. Chem., 2014, 53, 4639-4646.

53 N. E. Wezynfeld, T. Frączyk and W. Bal, Coord. Chem. Rev., 2016, 327-328, 166-187.

54 Y. Berezovskaya, C. T. Armstrong, A. L. Boyle, M. Porrini, D. N. Woolfson and P. E. Barran, Chem. Commun., 2011, 47, 412-414.

55 C. Harford and B. Sarkar, Acc. Chem. Res., 1997, 30, 123-130.

56 W. Bal, J. Christodoulou, P. J. Sadler and A. Tucker, J. Inorg. Biochem., 1998, 70, 33-39.

57 D. P. Mack and P. B. Dervan, Biochemistry, 1992, 31, 9399-9405.

58 W. Bal, J. Lukszo and K. S. Kasprzak, Chem. Res. Toxicol., 1997, 10, 915-921.

59 X. Huang, M. E. Pieczko and C. E. Long, Biochemistry, 1999, 38, 2160-2166.

60 Y. Y. Fang, C. A. Claussen, K. B. Lipkowitz and E. C. Long, J. Am. Chem. Soc., 2006, 128, 3198-3207.

61 C. Harford, S. Narindrasorasak and B. Sarkar, Biochemistry, 1996, 35, 4271-4278.

62 Y. Jin and J. A. Cowan, J. Am. Chem. Soc., 2005, 127, 8408-8415.

63 Y. Jin, M. A. Lewis, N. H. Gokhale, E. C. Long and J. A. Cowan, J. Am. Chem. Soc., 2007, 129, 8353-8361.

64 Z. Yu, M. Han and J. A. Cowan, Angew. Chem., Int. Ed., 2014, 53, 1901-1905.

65 E. Canaz, M. Kilinc, H. Sayar, G. Kiran and E. Ozyurek, J. Trace Elem. Med. Biol., 2017, 43, 217-223.

66 J. Jiménez-Lamana and J. Szpunar, Metallomics, 2017, 9, 1014-1027.

67 C. M. Agbale, M. H. Cardoso, I. K. Galyuona and O. L. Franco, Metallomics, 2016, 8, 1159-1169. 
68 H. Romanowicz-Makowska, E. Forma, M. Bryś, W. M. Krajewska and B. Smolarz, Pol. J. Pathol., 2011, 62, 257-261.

69 C. Zhao, X. Chen, D. Zang, X. Lan, S. Liao, C. Yang, P. Zhang, J. Wu, X. Li, N. Liu, Y. Liao, H. Huang, X. Shi, L. Jiang, X. Liu, Z. He, Q. P. Dou, X. Wang and J. Liu, Oncogene, 2016, 35, 5916-5927.

70 L. Wang, J. Fan, J. A. Hitron, Y.-O. Son, J. T. F. Wise, R. V. Roy, D. Kim, J. Dai, P. Pratheeshkumar, Z. Zhang and X. Shi, Toxicol. Sci, 2016, 151, 376-387.

71 A. Arita and M. Costa, Metallomics, 2009, 1, 222-228.

72 M. D. Libardo, J. L. Cervantes, J. C. Salazar and A. M. AngelesBoza, ChemMedChem, 2014, 9, 1892-1901.

73 B. L. Oakes, D. F. Xia, E. F. Rowland, D. J. Xu, I. a. Ankoudinova, J. S. Borchardt, L. Zhang, P. Li, J. C. Miller, E. J. Rebar and M. B. Noyes, Nat. Commun., 2016, 7, 10194.
74 L. S. Qi, M. H. Larson, J. A. Doudna, J. S. Weissmann, A. P. Arkin and W. A. Lim, Cell, 2013, 152, 1173-1183.

75 J. C. Miller, S. Tan, G. Qiao, K. A. Barlow, J. Wang, D. F. Xia, X. Meng, D. E. Paschon, E. Leung, S. J. Hinkley, G. P. Dulay, K. L. Hua, I. Ankoudinova, G. J. Cost, F. D. Urnov, H. S. Zhang, M. C. Holmes, L. Zhang, P. D. Gregory and E. J. Rebar, Nat. Biotechnol., 2011, 29, 143-148.

76 P. Yang, Y. Wang, D. Hoang, M. Tinkham, A. Patel, M.-A. Sun, G. Wolf, M. Baker, H.-C. Chien, K.-Y. N. Lai, X. Cheng, C.-K. J. Shen and T. S. Macfarlan, Science, 2017, 356, 757-759.

77 M. Imbeault, P.-Y. Helleboid and D. Trono, Nature, 2017, 543, 550-554.

78 A. Gutierrez-Guerrero, S. Sanchez-Hernandez, G. Galvani, J. Pinedo-Gomez, R. Martin-Guerra, A. Sanchez-Gilabert, A. Aguilar-González, M. Cobo, P. Gregory, M. Holmes, K. Benabdellah and F. Martin, Hum. Gene Ther., 2018, 29, 366-380. 